\title{
Differences in protein expression associated with ivermectin resistance in Caenorbabditis elegans
}

\author{
Diferenças na expressão de proteínas associadas à resistência à ivermectina em Caenorhabditis elegans \\ Dauana Mesquita Sousa ${ }^{1}$; Nivea Maria Ferreira da Cunha ${ }^{2}$; Deisianne Rodrigues da Silva ${ }^{2}$; \\ Paulo de Tarso Teles Dourado de Aragão ${ }^{3}$; Mônica Valéria de Almeida Aguiar²; Marina Duarte Pinto Lobo ${ }^{4}$; \\ Ana Cristina de Oliveira Monteiro Moreira ${ }^{4}$; Rodrigo Maranguape Silva da Cunha²; \\ Rodrigo Rodrigues Cambraia de Miranda ${ }^{2}$; Claudia Maria Leal Bevilaqua ${ }^{1 *}$ (D)

\begin{abstract}
${ }^{1}$ Laboratório de Doenças Parasitárias, Programa de Pós-graduação em Ciências Veterinárias, Faculdade de Veterinária, Universidade Estadual do Ceará - UECE, Fortaleza, CE, Brasil

${ }^{2}$ Laboratório de Biologia Molecular, Núcleo de Biotecnologia de Sobral, Universidade Estadual Vale do Acaraú - UVA, Sobral, CE, Brasil

${ }^{3}$ Laboratório de Biologia Molecular, Núcleo de Biotecnologia de Sobral, Programa de Pós-graduação em Biotecnologia, Universidade Federal do Ceará - UFC, Sobral, CE, Brasil

${ }^{4}$ Centro de Biologia Experimental, Universidade de Fortaleza - UNIFOR, Fortaleza, CE, Brasil
\end{abstract}

Received October 16, 2018

Accepted February 06, 2019

\begin{abstract}
The indiscriminate administration of synthetic anthelmintics such as ivermectin contributes to the selection of subpopulations capable of resisting the drugs' effects. To understand the mechanisms of ivermectin resistance in Caenorhabditis elegans, this study attempted to identify molecular targets. C. elegans lineages that were sensitive and resistant to ivermectin were used. Collected nematodes were added to an extraction buffer and macerated in liquid nitrogen for protein extraction. The extracted proteins were separated according to molecular weight by SDS-PAGE to verify their integrity. Subsequently, proteins from both lineages were separated using two-dimensional electrophoresis. The gels were analyzed and the relevant spots were excised and identified by mass spectrometry (NanoESI-Q-TOF and MASCOT $^{\circledR}$ ) and subsequently assessed by GO enrichment and STRING ${ }^{\circledR}$ analyses. The increased expression of proteins associated with high metabolic activity, such as ATP-2 and ENOL-1, which are responsible for ATP synthesis, was observed. Furthermore, proteins with involvement in mediating muscular function (MLC-1, ACT-1, and PDI-2), signaling (FAR-1 and FAR-2), and embryo development (VHA-2) were identified. Protein interaction analysis indicated that the majority of the identified proteins in the resistant lineages participated in the same reaction triggered by ivermectin.
\end{abstract}

Keywords: Caenorhabditis elegans, proteomics, resistance, ivermectin.

\section{Resumo}

A administração indiscriminada de anti-helmínticos sintéticos, como a ivermectina, contribui para a seleção de subpopulaçóes capazes de resistir ao efeito das drogas. Para entender os mecanismos de resistência à ivermectina em Caenorhabditis elegans, este estudo visou identificar alvos moleculares. Portanto, linhagens de C. elegans sensíveis e resistentes à ivermectina foram utilizadas. Os nematóides coletados foram adicionados ao tampão de extração e macerados em nitrogênio líquido para obtenção das proteínas. As proteínas extraídas foram separadas por peso molecular em SDS-PAGE para verificar sua integridade. Posteriormente, as proteínas de ambas as linhagens foram separadas por eletroforese bidimensional. Os géis foram analisados, os spots relevantes foram excisados e identificados por espectrometria de massa (NanoESI-Q-TOF e MASCOT ${ }^{\circledR}$ ), em seguida, analisados em seus termos de GO e STRING ${ }^{\circledR}$. A expressáo aumentada de proteínas associadas à alta atividade metabólica, como as proteínas ATP-2 e ENOL-1, responsáveis pela síntese de ATP, foi observada. Além disso, foram identificadas as proteínas responsáveis pelo controle da função muscular (MLC-1, ACT-1 e PDI-2), sinalização (FAR-1 e FAR-2) e desenvolvimento embrionário (VHA-2). A análise das interaçóes proteicas indicou que a maioria das proteínas identificadas na cepa resistente participa da mesma reação desencadeada pela ivermectina.

Palavras-chave: Caenorhabditis elegans, proteômica, resistência, ivermectina. 


\section{Introduction}

Anthelmintic resistance is a problem that plagues livestock production worldwide, causing a billion dollars in losses annually (CHARLIER et al., 2009). This problem is caused by the parasites' ability to survive the drugs used to treat helminthiasis (GOOLSBY et al., 2017).

There are several groups of drugs that are differentiated by their chemical formulas and mechanisms of action to control helminth parasites (KAPLAN \& VIDYASHANKAR, 2012). Among the most heavily studied of these drugs, ivermectin is a semisynthetic compound derived from an actinomycete with a broad spectrum of action (CAMPBELL, 2012). Although ivermectin follows the parameters recommended for good anthelmintics, resistance to this drug was reported in the first years after its launch (VAN WYK \& MALAN, 1988). There is no explanation to date for ivermectin resistance, only hypotheses that consider changes in the chlorine receptor channels and p-glycoproteins, which are membrane proteins responsible for the cellular efflux of drugs (LESPINE et al., 2012).

Several protein changes occur in response to stress caused by various factors, such as temperature, food, radiation exposure, and chemicals (CEDERGREEN et al., 2016). Additionally, these changes can even be caused by genetic selection of the subpopulation to resist a stress environment promoted by drug compounds. It is possible to identify these proteins in proteomic studies, such as two-dimensional electrophoresis (2DE) associated with mass spectrometry, which emphasizes differences in expressiveness and concentrations (HART et al., 2015).

Although 2DE associated with mass spectrometry is a safe tool for identification, it is not possible to identify proteins when there is no information available in databases (TABUSE et al., 2005). Therefore, studies of model organisms are preferred because they are associated with large datasets, and findings obtained in these organisms can be extrapolated to other organisms that have been less heavily researched (ANTOSHECHKIN \& STERNBERG, 2007).

For this study, we used the model Caenorhabditis elegans, a nematode that can be handled efficiently under laboratory conditions and compared with parasitic nematodes. Among this model's notable qualities is the ability to be manipulated genetically to develop parasite characteristics, such as ivermectin resistance (BRENNER, 1974; AUDHYA \& DESAI, 2008). The aim of this study was to compare the main protein differences between lineages of $C$. elegans that are sensitive and resistant to ivermectin. The results may help to explain the mechanism of resistance to ivermectin in nematodes.

\section{Materials and Methods}

\section{Strains of Caenorhabditis elegans}

The wild-type lineage of $C$. elegans Bristol N2 was provided by Dr. Carlos Winter (Department of Parasitology/ICB/USP). The lineage was maintained on nutrient growth medium (NGM) agar in Petri dishes at $20^{\circ} \mathrm{C}$ (BRENNER, 1974). The lineage resistant to $15 \mathrm{ng} / \mathrm{mL}$ ivermectin $\left(\mathrm{IVR}_{15}\right.$ ) was developed stepwise in plates containing NGM with the addition of doses $(1 \mathrm{ng} / \mathrm{ml})$ of ivermectin, according to James \& Davey (2009).

\section{Protein extraction}

The lineages, containing the all larval stages and eggs, were collected in $\mathrm{M} 9$ buffer $\left(\mathrm{Na}_{2} \mathrm{HPO}_{4} \cdot 7 \mathrm{H}_{2} \mathrm{O}, \mathrm{KH}_{2} \mathrm{PO} 4, \mathrm{NaCl}\right.$, $\mathrm{MgSO}_{4} .7 \mathrm{H} 2 \mathrm{O}, \mathrm{ddH}_{2} \mathrm{O}$ ) and centrifuged at $1000 \mathrm{xg}$ for one minute to remove the buffer. For each lineage, we added extraction buffer (1\% CHAPS, 100mM DTT, $7 \mathrm{M}$ urea, $2 \mathrm{M}$ thiourea) in a 1:1 proportion to the nematode pool, followed by immersion in liquid nitrogen, maceration, and centrifugation at $13000 \times \mathrm{g}$ at $4^{\circ} \mathrm{C}$ for 5 minutes; then, the supernatant was subjected to electrophoresis (SILVA et al., 2014).

The extraction quality was observed using polyacrylamide gel electrophoresis in the presence of sodium dodecyl sulfate (SDS-PAGE). The samples were loaded, and the gels were stained with Coomassie brilliant blue R-250 solution (SAMBROOK \& DAVID, 2006).

\section{Two-dimensional electrophoresis and image analysis}

The 2DE gels were made induplicate for each lineage using $50 \mu \mathrm{g}$ of the protein pool. The protein samples were pooled with $250 \mu \mathrm{l}$ of rehydration buffer (7 M urea, $2 \mathrm{M}$ thiourea, $1 \%$ CHAPS, $1 \%$ DTT, $0.5 \%$ ampholytes, $\mathrm{pH} 3-10$, trace of bromophenol blue) and subjected to $2 \mathrm{DE}$ electrophoresis.

The samples were subjected to isoelectric focusing (IEF) using Ettan IPGphor III (GE Healthcare). The linear IPG strips $(\mathrm{pH} 3-10,13 \mathrm{~cm})$ were equilibrated with solution I (6 M urea, $50 \mathrm{mM}$ Tris, $30 \%$ glycerol, $2 \%$ SDS, $1 \%$ DTT and a trace of bromophenol blue) for 15 minutes with shaking. This step was repeated for equilibration solution II (6 M urea, $50 \mathrm{mM}$ Tris, 30\% glycerol, 2\% SDS, $1 \%$ DTT, trace of bromophenol blue and 3\% iodoacetamide). The strips were embedded on the top of $12 \%$ polyacrylamide gels and separated using the Hoefer SE 600 Ruby system (GE Healthcare). The gels were stained with Coomassie brilliant blue G-250 (CANDIANO et al., 2004). The gels were scanned (LabScan, GE Healthcare), and the images were saved in the TIFF format for spot detection, quantification, matching and differential analysis with the ImageMaster 2D Platinum program (GE Healthcare). Matched spots were compared for volume, with p-values less than 0.05 being considered significant, and histograms were generated by classifying the spots according to their quantitative expressiveness.

\section{Two-dimensional gel excision and mass spectrometry}

The differentially expressed and exclusively expressed spots were selected and excised manually, followed by digestion with trypsin according to Shevchenko et al. (2006). The tryptic peptide samples were analyzed by NanoESI-Q-TOF coupled with nanoUPLC. The data obtained were submitted to the MASCOT sequence query server (MÁDI et al., 2008) for identification against the NCBIprot database and the SwissProt database. The results were 
evaluated by observing the best probability score and the number of peptides matched for each spot identified.

a. Gene ontology

Using the BLAST ${ }^{\circledR}$ option Blastp, the proteins identified in both lineages were compared with sequences in the NCBI database (MADDEN, 2013). The accession numbers were submitted to the tool Retrieve/ID Mapping of the UniProt database. The data were converted into Gene Ontology (GO) terms and grouped into categories: Molecular Function, Biological Process and Cellular Component.

\section{b. Protein interactions}

The sequences of the proteins exclusively expressed in lineage $\operatorname{IVR}_{15}$, as identified by MS, were acquired in BLAST and submitted to the protein-protein interaction program STRING, version 10.0, according to the standard protocol (SZKLARCZYK et al., 2017). The interactions were predicted per co-occurrence and co-expression and were determined experimentally.

\section{Results}

\section{SDS-PAGE and two-dimensional electrophoresis}

The efficiency of the extraction method and the quality of the extracted proteins were confirmed by SDS-PAGE, enabling the analysis of protein expression changes between the lineages to be performed in two-dimensional gels (Figure 1). The replicate2DEgels were compared, and their matching generated a linear correlation coefficient of 0.853 for N2 and 0.806 for $\operatorname{IVR}_{15}$ (Figure 2).

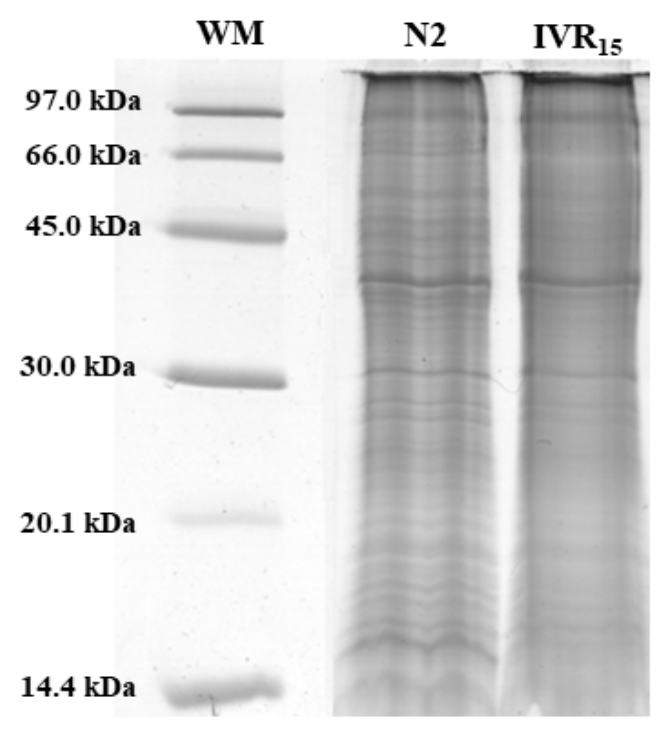

Figure 1.SDS-PAGE of the proteins of $C$. elegans lineages sensitive (N2) and resistant to ivermectin $\left(\mathrm{IVR}_{15}\right)$. Notes: $\mathrm{kDa}$ - Kilodalton; WM - Weight Molecular; N2 - Lineage wild-type of C. elegans Bristol $\mathrm{N} 2$ IVR $_{15}$ - Lineage resistant to $15 \mathrm{ng} / \mathrm{mL}$ ivermectina.
The proteome profiles demonstrated that there were differences in the protein expression as a function of anthelmintic resistance (Figure 3). Although the number of spots remained relatively similar, the protein expression was $7 \%$ higher in the resistant lineage than in the sensitive lineage, which was beyond the changes observed in the protein distribution by $\mathrm{pI}$ and molecular weight.

\section{Mass Spectrometry (MS)}

Twenty-three spots of each lineage were chosen for analysis by MS. Among those spots, 10 were considered more expressed, and 13 were exclusively expressed in both lineages. The identified proteins of the N2 lineage and those of the $\mathrm{IVR}_{15}$ lineage are listed in Table 1. After identification, two proteins found in the two lineages were similar: disulfide isomerase 2 (PDI-2) and ATP synthase subunit beta (ATP-2). Proteins that were uncharacterized but deposited in the UniProt data base were also found in each lineage. The intermediate filament protein (IFB-2) was identified in two spots of lineage N2, with each having a high score. Fatty acid and retinol-binding protein 1 (FAR-1) and fatty acid and retinol-binding protein 2 (FAR-2), belonging to the same family and possessing similar features, were found in $\mathrm{IVR}_{15}$.

\section{Gene Ontology (GO)}

The proteins identified were grouped according to GO terms and are listed in Tables 2 and 3. Lineage N2 had three proteins predicted for Molecular Function, nine for Cellular Component, and five for Biological Process. The distribution of the proteins was different between the $\mathrm{IVR}_{15}$ lineage and the N2 lineage, principally regarding Biological Process with 11 proteins.

\section{Protein interactions}

The protein interactions exclusively expressed by the $\mathrm{IVR}_{15}$ lineage are presented in Figure 4. ENOL-1, ACT-1, PDI-2, and ATP-2 have been predicted to interact by co-expression and textmining, and there are also interactions that were experimentally determined. Beyond the interaction described previously, PDI-2, ATP-2, and VHA-12 demonstrated homology according to curated databases. The FAR-1 and FAR-2 proteins were co-expressed and textmined. However, no interaction was predicted among MLC-1, C35B1.1 and the other proteins exclusively expressed as mentioned above.

\section{Discussion}

Ivermectin acts upon chlorine channels controlled by glutamate, causing hyperpolarization of the cellular membrane which paralyzes the muscular system. However, some nematodes are able to withstand the selection pressure promoted by the anthelmintics (IKEDA, 2003). To understand anthelmintic resistance to ivermectin, the two mechanisms of study were adopted: (I) Specific mechanism, result of the modification and/or change in the drug receptor and (II) Unspecific mechanism, characterized by cellular detoxification using proteins considered to be efflux pumps (RAZA et al., 2016). 

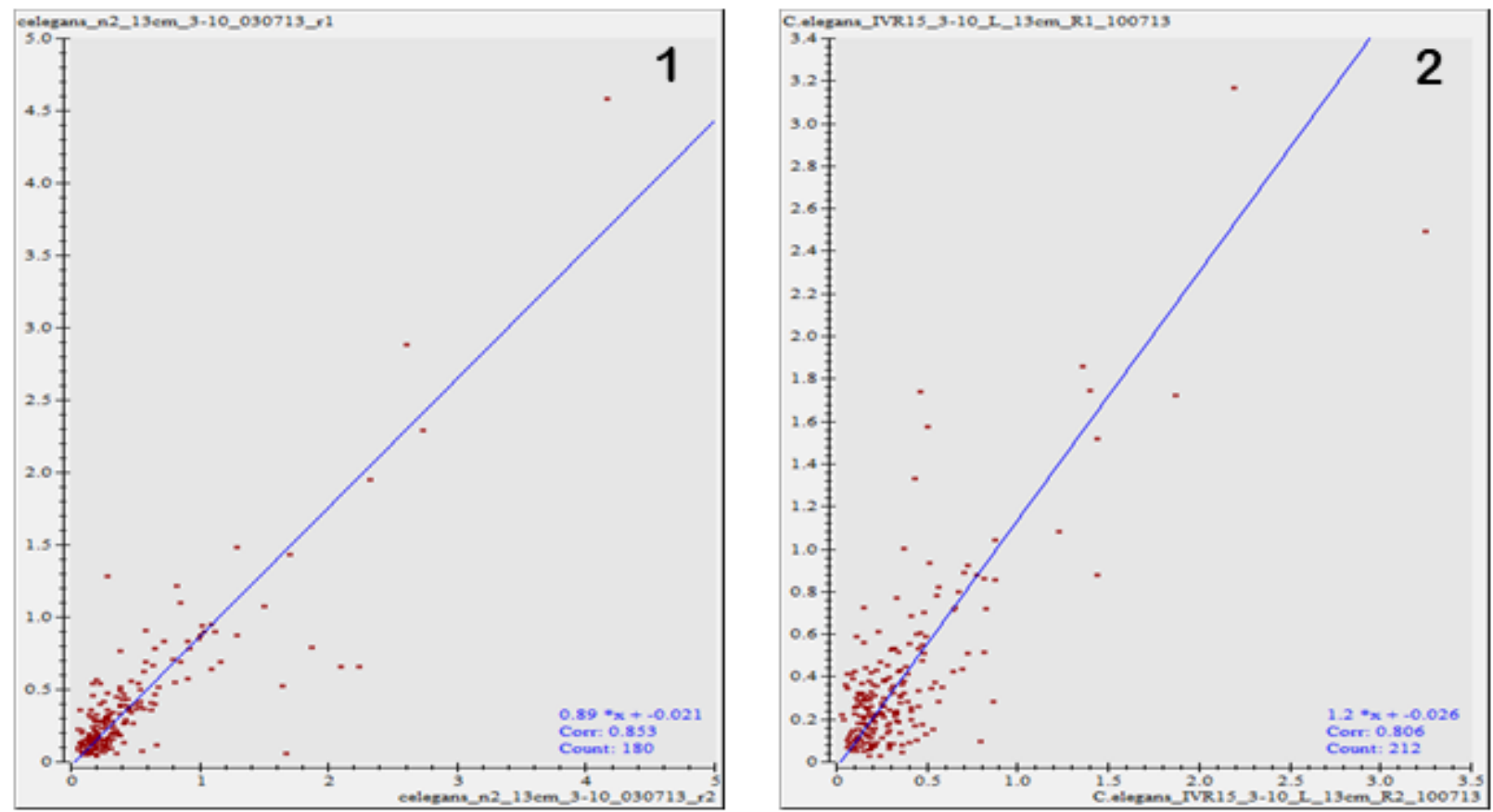

Figure 2. Scatter plot of protein samples from C. elegans N2 (1) and $\mathrm{IVR}_{15}$ (2) lineages. Notes: Corr - Correlation coefficient; Count - Countage of spots.

Table 1. Proteins with modified expression in ivermectin-sensitive lineage, proteins more expressed and proteins exclusively expressed ivermectin-resistant lineages from C. elegans were identified by mass spectrometry NanoESI-Q-TOF.

\begin{tabular}{|c|c|c|c|c|c|c|c|}
\hline Proteins & Spot & Entry & ID & Gene & Mass & Score & Peptide \\
\hline \multirow[t]{7}{*}{$\begin{array}{l}\text { More expressed } \\
\text { N2 }\end{array}$} & 954 & Q19286 & 2::IFB2_CAEEL & $\begin{array}{l}\text { Intermediate filament protein } \\
\text { ifb-2 }\end{array}$ & 61688 & 95 & R.YAAILDEEKR.L \\
\hline & 944 & Q17770 & PDI2_CAEEL & Protein disulfide-isomerase 2 & 55346 & 194 & R.LISLEEDMTK.F \\
\hline & 965 & Q20780 & NP_498081.2 & Aldehyde dehydrogenase & 55309 & 44 & K.VAFTGSTEVGR.L \\
\hline & 935 & Q23621 & NP_502267.1 & Glutamate dehydrogenase & 59214 & 84 & K.VLYITFPIR.R \\
\hline & 927 & Q19286 & IFB2_CAEEL & $\begin{array}{l}\text { Intermediate filament protein } \\
\text { ifb- } 2\end{array}$ & 61688 & 94 & R.YAAILDEEKR.L \\
\hline & 2208 & G5EGM4 & NP_510310.1 & $\begin{array}{c}\text { Uncharacterized protein CELE_ } \\
\text { M03B6.3 }\end{array}$ & 72163 & 46 & K.KMEEELR.K \\
\hline & 1071 & Q19286 & ATPB_CAEEL & $\begin{array}{c}\text { ATP synthase subunit beta, } \\
\text { mitochondrial }\end{array}$ & 57662 & 41 & K.FVSLEETIR.G \\
\hline \multirow{5}{*}{$\begin{array}{l}\text { More expressed } \\
\text { IVR }_{15}\end{array}$} & 113 & Q27527 & ENO_CAEEL & Enolase & 46759 & 90 & K.VNQIGSVTESIEAAK.L \\
\hline & 297 & P19625 & MLR1_CAEEL & Myosin regulatory light chain 1 & 18662 & 60 & K.GKPPIEGGEVDYK.A \\
\hline & 102 & Q19626 & VATB_CAEEL & $\begin{array}{c}\text { Probable V-type proton ATPase } \\
\text { subunit B }\end{array}$ & 55001 & 213 & K.IPIFSASGLPHNEIAAQIVR.Q \\
\hline & 89 & Q17770 & PDI2_CAEEL & Protein disulfide-isomerase 2 & 55346 & 160 & K.FADDESIVIAK.M \\
\hline & 106 & P46561 & ATPB_CAEEL & $\begin{array}{l}\text { ATP synthase subunit beta, } \\
\text { mitochondrial }\end{array}$ & 57662 & 184 & R.FTQAGSEVSALLGR.I \\
\hline \multirow[t]{4}{*}{$\begin{array}{l}\text { Exclusively } \\
\text { expressed IVR } \\
15\end{array}$} & 1182 & O45060 & NP_500478.1 & $\begin{array}{l}\text { Uncharacterized protein CELE_ } \\
\text { C35B1.5 }\end{array}$ & 17069 & 75 & K.KYEVPTIPAFK.L \\
\hline & 319 & P34383 & FAR2_CAEEL & $\begin{array}{l}\text { Fatty-acid and retinol-binding } \\
\text { protein } 2\end{array}$ & 20023 & 41 & K.GLIPAEVAEHLK.A \\
\hline & 233 & P0DM41 & ACT1_CAEEL & Actin-1 & 42111 & 50 & R.GYSFTTTAER.E \\
\hline & 1178 & P34382 & FAR1_CAEEL & $\begin{array}{l}\text { Fatty-acid and retinol-binding } \\
\text { protein } 1\end{array}$ & 20097 & 39 & K.SLIPAEVSEHLK.S \\
\hline
\end{tabular}

NanoESI-Q-TOF - Nano-electrospray ionization quadrupole time-of-flight; N2 - Lineage wild-type of C. elegans Bristol N2; IVR ${ }_{15}$ - Lineage resistant to 15 ng/mL ivermectin; ATP - Adenosine triphosphate; CELE - Caenorhabditis elegans. 

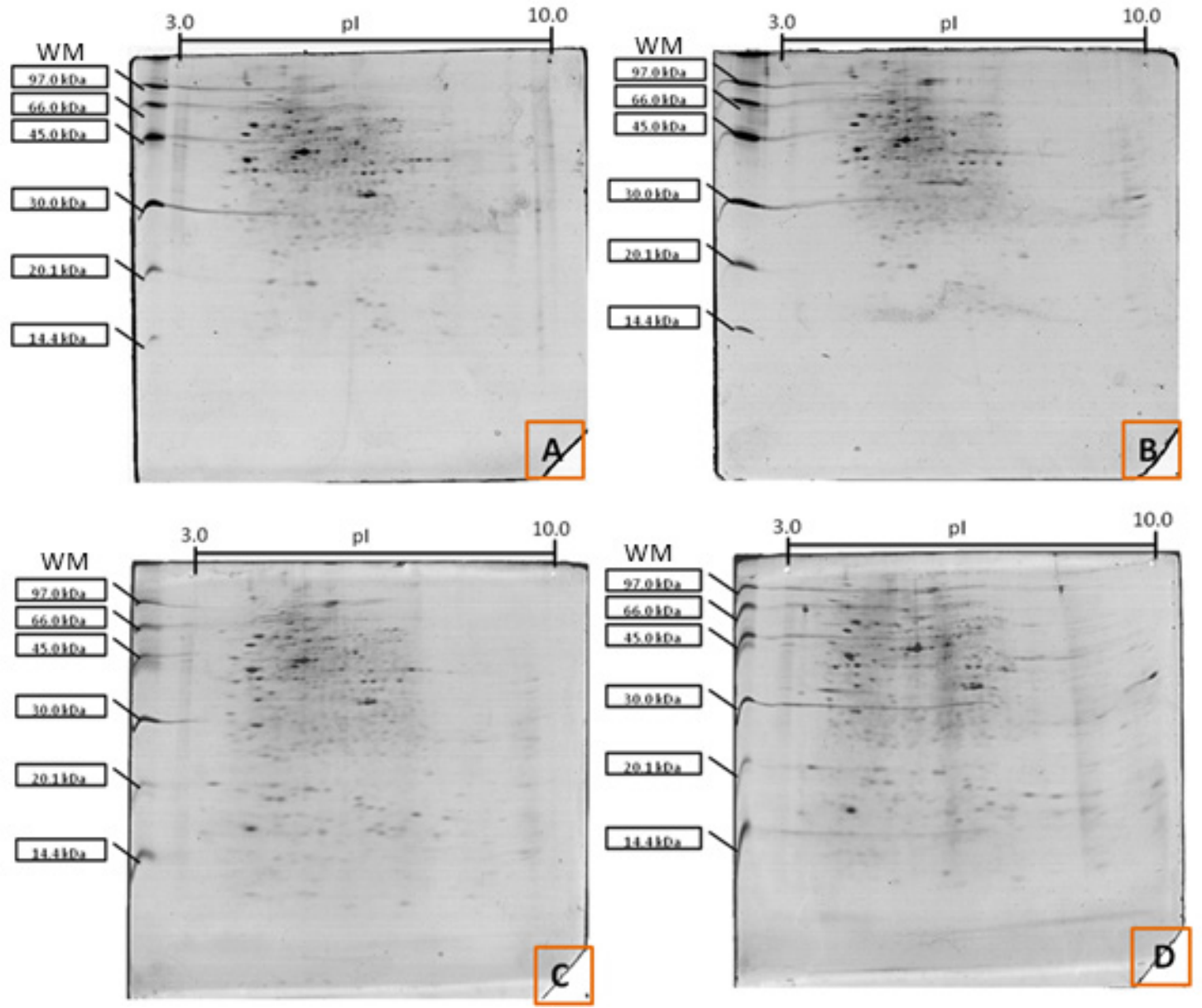

Figure 3. Two-dimensional electrophoresis gels with protein samples from the N2 (A and B) and IVR ${ }_{15}(\mathrm{C}$ and D) lineages of C. elegans. Notes: pI - Isoeletric point; WM - Weight Molecular; kDa - Kilodalton.

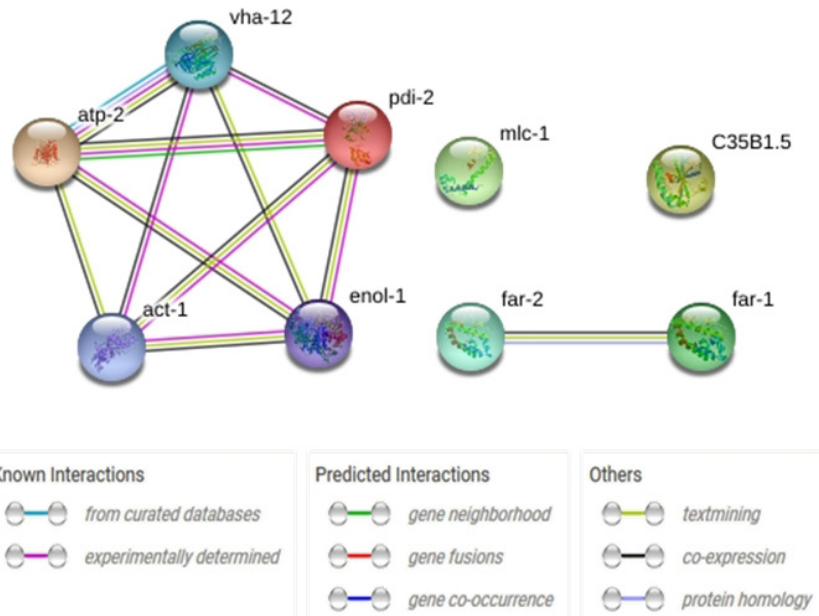

Figure 4. Interaction network of the proteins exclusively expressed in the IVR $_{15}$ lineage using STRING. Notes: VHA-12 - Probable V-type proton ATPase subunit B; PDI-2 - Protein disulfide-isomerase 2; ENOL-1 - Enolase 1; ACT-1 - Actin-1; ATP-2 - ATP synthase subunit beta, mitochondrial; MLC-1 - Myosin regulatory light chain 1; FAR-1 - Fatty-acid and retinol-binding protein 1; FAR-2 - Fatty-acid and retinol-binding protein 2; C35B1.3 - Uncharacterized protein CELE_C35B1.5.
Therefore, to observe the protein alterations caused by ivermectin in the $C$. elegans-resistant lineage, it was necessary to use the wild-type lineage as a parameter because the $\mathrm{IVR}_{15}$ was not precisely identical to the field conditions faced by parasite nematodes because it does not occur in a controlled and standardized form. However, the genetic selection of the $\mathrm{IVR}_{15}$ lineage represents an excellent alternative to understanding the molecular puzzle associated with anthelmintic resistance against ivermectin in nematodes (JAMES \& DAVEY, 2009).

Thus, comparing the protein expression between $\mathrm{IVR}_{15}$ and N2, it was possible to identify the most highly expressed or exclusively expressed proteins (Table 1), which have not been associated with anthelmintic resistance in nematodes to date. The comparison was made initially by the classification of differentially expressed proteins in the N2 lineage for the respective GO terms. The molecular function group was divided into categories: (1) oxidoreductase, (2) catalytic, and (3) structural molecular. According to the Biological Process predictions, we inferred that the proteins were involved in the (1) cellular process, (2) metabolism and (3) stimuli responses. Janssen et al. (2013) highlighted that $C$. elegans possesses a greater demand for proteins responding to environmental interference than rodents and humans. C. elegans is part of a habitat full of ecological interactions, it is a free-living organism in direct contact 
with the soil. Thus, it is observed that the expression of proteins that respond to environmental stimuli is maintained even when C. elegans develops in vitro and in ideal conditions.

Table 2. Predicted functions of the proteins identified in the C. elegans lineage sensitive to ivermectin by gene ontology annotation.

\begin{tabular}{llc}
\hline \multicolumn{1}{c}{ Level 1 } & \multicolumn{1}{c}{ Level 2 N2 } & $\begin{array}{c}\text { Proteins } \\
\text { Counts N2 }\end{array}$ \\
\hline Molecular & Catalytic activity & 3 \\
function & Oxiredutase activity & 2 \\
& Structural molecule activity & 1 \\
& Cell part & 2 \\
& Cytoskeletal part & 1 \\
& Endoplasmic reticulum & 1 \\
Cellular & Endoplasmic reticulum lumen & 1 \\
component & Endoplasmic reticulum lumen & 1 \\
& Endoplasmic reticulum part & 1 \\
& Intermediate filament & 1 \\
& Intracellular organelle & 2 \\
& Procollagen-proline 4-dioxygenase & 1 \\
& complex & 1 \\
Biological & Biological regulation & 2 \\
process & Cellular process & Retabolic process \\
& Single-organism process & 2 \\
\hline
\end{tabular}

N2 - Lineage wild-type of C. elegans Bristol N2.

Table 3. Predicted functions of the proteins identified in the C. elegans lineage resistant to ivermectin by gene ontology annotation.

\begin{tabular}{|c|c|c|}
\hline Level 1 & Level 2 IVR $_{15}$ & $\begin{array}{c}\text { Proteins } \\
\text { Counts IVR } \\
\end{array}$ \\
\hline \multirow{6}{*}{$\begin{array}{l}\text { Molecular } \\
\text { function }\end{array}$} & Binding & 6 \\
\hline & Catalytic activity & 2 \\
\hline & Transporter activity & 1 \\
\hline & Cell part & 4 \\
\hline & Extracellular region & 2 \\
\hline & Macromolecular complex & 3 \\
\hline \multirow{6}{*}{$\begin{array}{l}\text { Cellular } \\
\text { component }\end{array}$} & Organelle & 2 \\
\hline & Organelle membrane & 1 \\
\hline & Organelle part & 2 \\
\hline & $\begin{array}{l}\text { Proton-transporting ATP synthase } \\
\text { complex, catalytic core } \mathrm{F}(1)\end{array}$ & 1 \\
\hline & Behavior & 2 \\
\hline & Cellular process & 3 \\
\hline \multirow{9}{*}{$\begin{array}{l}\text { Biological } \\
\text { process }\end{array}$} & Developmental process & 3 \\
\hline & Localization & 1 \\
\hline & Locomotion & 2 \\
\hline & Metabolic process & 2 \\
\hline & Multicellular organismal process & 3 \\
\hline & Organelle organization & 1 \\
\hline & Regulation of muscle contraction & 1 \\
\hline & Reproductive process & 1 \\
\hline & Single-organism process & 4 \\
\hline
\end{tabular}

$\mathrm{IVR}_{15}$ - Lineage resistant to $15 \mathrm{ng} / \mathrm{mL}$ ivermectin.
The protein expression profile of the $\operatorname{IVR}_{15}$ (Table 1) lineage shows variations in the distribution in their $\mathrm{GO}$ terms related to the N2 lineage (Table 2). The main differences were demonstrated in the classification according to the molecular function. The proteins were divided into (1) ligands, (2) catalytic activity and (3) transport activity. This result suggests an increase in metabolic rate and elimination of substances that can destabilize natural cell organization.

Proteins with increased expression in $\mathrm{IVR}_{15}$ corroborate the results acquired in the classifications of the GO terms (Table 3 ). The maintenance of high metabolic rates requires proportional energetic production. Furthermore, the expression of such proteins as the ATP synthase $\beta$ subunit (ATP-2) and enolase-1 (ENOL-1) is necessary to supply the nematode energetic needs to maintain cellular stability. ATP-2 is responsible for coding a part of ATP synthase, which is important inaerobic respiration and energetic production (DURAI et al., 2014). ENOL-1facilitates the ATP formation process during glycolysis, inducing the activation of heat-shock proteins and helping in the larval development and in the apoptosis inhibition (LUO et al., 2017). The findings of Chen et al. (2012) confirm the results of this study, suggesting a change in the amount of ATP due to the change in the production of ENOL-1.

To maintain balanced physiological processes, the increase in the expression of the $\beta$ subunit of V-type ATPase (VHA-12) in the C. elegans-resistant lineage contributes to embryo development under adverse conditions. Ernstrom et al. (2012) silenced the VHA-12 gene in C. elegans and verified that it does not influence oogenesis or spermatogenesis in the germinative line of the adult phase, although it can assist in the initial embryo development process. VHA-12 promotes acidification in synaptic vesicles, acting in neurotransmitter normalization using a positive membrane potential in the cellular interior in adult nematode nervous cells and suppressing cellular necrosis (ROST et al., 2015). This function allows ivermectin-resistant nematodes to maintain nervous impulse transmission, thereby ensuring normal muscle contraction among other benefits.

In addition, to complement the neuromuscular effect of VHA-12, there was an increase in the production of protein myosin regulatory light chain 1 (MLC-1) and disulfide isomerase 2 (PDI-2). Usually, MLC is found in the entire body of the nematode (RUSHFORTH et al., 1998). Li et al. (2010) observed an increase in MLC-1 expression that affects the cytoskeleton of nematodes subject to stress by hypoxia. Conversely, PDI-2 is important in collagen matrix formation and is located in the hypodermis, where it helps to maintain nematode physiology, cellular homeostasis and protect against stress in the endoplasmic reticulum, the site responsible for the unfolding of secreted proteins (DURAI et al., 2014). Among the exclusively expressed proteins of the $I_{V R}$ lineage, actin-1 (ACT-1) joins the PDI-1 and MLC-1 proteins to ensure nematode muscular viability because ACT-1 is responsible for cytoskeletal formation in addition to muscular regions and myofilaments (MACQUEEN et al., 2005).

The other exclusively expressed proteins in $\mathrm{IVR}_{15}$ were the fatty acid and retinol-binding proteins 1 and 2 (FAR-1 and FAR-2) and C35B1.5 protein. The FAR-1 and FAR-2 proteins have six other isoforms described in C. elegans, which are localized in the 
cell membrane and are related to cell signaling and the immune response. Previous studies showed the bound capacity of these proteins in anthelmintics, such as albendazole, levamisole, abamectin, and praziquantel (REY-BURUSCO et al., 2015; QIAO et al., 2016). Thus, it is possible to suggest that FAR-1 and FAR-2 promote ivermectin resistance mechanisms by triggering biological signaling in addition to their possible role in recruiting fatty acids to contribute to the maintenance of energetic balance during the stress induced by the anthelmintic agent. Moreover, new studies detailing the process and the possible signaling pathways of FAR-1 and FAR-2 proteins are warranted. Furthermore, a database enrichment of $\mathrm{C} 35 \mathrm{~B} 1.5$ protein is needed because there is not enough information available at present. It is known that this protein is detected in excretory cells, germ cells, the intestine and GABA-like excitatory neuronal receptors (SHAYE \& GREENWALD, 2011)

The proteins identified in the $\mathrm{IVR}_{15}$ lineage were mapped and there was no identification of p-glycoprotein as expected for the resistant lineage. We suggest that this fact is a consequence of the technique used, since Hart et al. (2015) using the same technique reported similar results. Figueiredo et al. (2018) identified p-glycoproteins using gene expression mapping. The proteins identified when compared with the database showed co-expression among themselves. This finding suggests that co-expression is triggered as a response to stress caused by ivermectin, highlighting the series response that makes $C$. elegans lineage resistant.

In conclusion, we can observe that the results obtained by identifying new proteins exclusively and differentially expressed associated ivermectin resistance in C. elegans, as well as the studies of molecular interactions, provided new data regarding the defense mechanism utilized by the nematode during resistant lineage selection. Based on the collected data, we observed a possible contraposition to ivermectin action in all affected tissues through the augmented expression of proteins related to cellular and structural viability, energy production, survival and nematode reproduction under the tested conditions. In addition, these results point to proteins that can be employed to help characterize and monitor anthelmintic resistance to ivermectin.

\section{Acknowledgements}

The authors would like to thank FUNCAP and CNPq for providing financial support and UNIFOR for providing infrastructure support. Dr. Bevilaqua received a research fellowship from $\mathrm{CNPq}$ (310663/2016-4).

\section{References}

Antoshechkin I, Sternberg PW. The versatile worm: genetic and genomic resources for Caenorhabditis elegans research. Nat Rev Genet 2007; 8(7): 518-532. http://dx.doi.org/10.1038/nrg2105. PMid:17549065.

Audhya A, Desai A. Proteomics in Caenorhabditis elegans. Brief Funct Genomic Proteomic 2008; 7(3): 205-210. http://dx.doi.org/10.1093/ bfgp/eln014. PMid:18372286.
Brenner S. The genetics of Caenorhabditis elegans. Genetics 1974; 77(1): 71-94. PMid:4366476.

Campbell W. History of avermectin and ivermectin, with notes on the history of other macrocyclic lactone antiparasitic agents. Curr Pharm Biotechnol 2012; 13(6): 853-865. http://dx.doi.org/10.2174/138920112800399095. PMid:22039784.

Candiano G, Bruschi M, Musante L, Santucci L, Ghiggeri GM, Carnemolla B, et al. Blue silver: a very sensitive colloidal Coomassie G-250 staining for proteome analysis. Electrophoresis 2004; 25(9): 1327-1333. http:// dx.doi.org/10.1002/elps.200305844. PMid:15174055.

Cedergreen N, Norhave NJ, Svendsen C, Spurgeon DJ. Variable temperature stress in the nematode Caenorhabditis elegans (maupas) and its implications for sensitivity to an additional chemical stressor. PLoS One 2016; 11(1): e0140277. http://dx.doi.org/10.1371/journal. pone.0140277. PMid:26784453.

Charlier J, Höglund J, von Samson-Himmelstjerna G, Dorny P, Vercruysse J. Gastrointestinal nematode infections in adult dairy cattle: Impact on production, diagnosis and control. Vet Parasitol 2009; 164(1): 70-79. http://dx.doi.org/10.1016/j.vetpar.2009.04.012. PMid:19414223.

Chen N, Yuan ZG, Xu MJ, Zhou DH, Zhang XX, Zhang YZ, et al. Ascaris suum enolase is a potential vaccine candidate against ascariasis. Vaccine 2012; 30(23): 3478-3482. http://dx.doi.org/10.1016/j. vaccine.2012.02.075. PMid:22465737.

Durai S, Singh N, Kundu S, Balamurugan K. Proteomic investigation of Vibrio alginolyticus challenged Caenorhabditis elegans revealed regulation of cellular homeostasis proteins and their role in supporting innate immune system. Proteomics 2014; 14(15): 1820-1832. http://dx.doi.org/10.1002/ pmic.201300374. PMid:25044714.

Ernstrom GG, Weimer R, Pawar DRL, Watanabe S, Hobson RJ, Greenstein D, et al. V-ATPase V 1 sector is required for corpse clearance and neurotransmission in Caenorhabditis elegans. Genetics 2012; 191(2): 461-475. http://dx.doi.org/10.1534/genetics.112.139667. PMid:22426883.

Figueiredo LA, Rebouças TF, Ferreira SR, Rodrigues-Luiz GF, Miranda $\mathrm{RC}$, Araujo RN, et al. Dominance of P-glycoprotein 12 in phenotypic resistance conversion against ivermectin in Caenorhabditis elegans. PLoS One 2018; 13(2): e0192995. http://dx.doi.org/10.1371/journal. pone.0192995. PMid:29474375.

Goolsby MK, Leite-Browning ML, Browning RB Jr. Evaluation of parasite resistance to commonly used commercial anthelmintics in meat goats on humid subtropical pasture. Small Rumin Res 2017; 146: 37-40. http:// dx.doi.org/10.1016/j.smallrumres.2016.11.022.

Hart EH, Brophy PM, Prescott M, Bartley DJ, Wolf BT, Hamilton JV. A new enabling proteomics methodology to investigate membrane associated proteins from parasitic nematodes: case study using ivermectin resistant and ivermectin susceptible isolates of Caenorhabditis elegans and Haemonchus contortus. Vet Parasitol 2015; 207(3-4): 266-275. http:// dx.doi.org/10.1016/j.vetpar.2014.12.003. PMid:25537855.

Ikeda T. Pharmacological effects of ivermectin, an antiparasitic agent for intestinal strongyloidiasis: its mode of action and clinical efficacy. Nippon Yakurigaku Zasshi 2003; 122(6): 527-538. http://dx.doi.org/10.1254/ fpj.122.527. PMid:14639007.

James CE, Davey MW. Increased expression of ABC transport proteins is associated with ivermectin resistance in the model nematode Caenorhabditis elegans. Int J Parasitol 2009; 39(2): 213-220. http://dx.doi.org/10.1016/j. ijpara.2008.06.009. PMid:18708066. 
Janssen IJI, Krücken J, Demeler J, von Samson-Himmelstjerna G. Caenorhabditis elegans: modest increase of susceptibility to ivermectin in individual P-glycoprotein loss-of-function strains. Exp Parasitol 2013; 134(2): 171-177. http://dx.doi.org/10.1016/j.exppara.2013.03.005. PMid:23518455.

Kaplan RM, Vidyashankar AN. An inconvenient truth: global worming and anthelmintic resistance. Vet Parasitol 2012; 186(1-2): 70-78. http:// dx.doi.org/10.1016/j.vetpar.2011.11.048. PMid:22154968.

Lespine A, Ménez C, Bourguinat C, Prichard RK. P-glycoproteins and other multidrug resistance transporters in the pharmacology of anthelmintics: Prospects for reversing transport-dependent anthelmintic resistance. Int J Parasitol Drugs Drug Resist 2012; 2: 58-75. http://dx.doi.org/10.1016/j. ijpddr.2011.10.001. PMid:24533264.

Li H, Ren C, Shi J, Hang X, Zhang F, Gao Y, et al. A proteomic view of Caenorhabditis elegans caused by short-term hypoxic stress. Proteome Sci 2010; 8(1): 49. http://dx.doi.org/10.1186/1477-5956-8-49. PMid:20858264.

Luo X, Shi X, Yuan C, Ai M, Ge C, Hu M, et al. Genome-wide SNP analysis using $2 \mathrm{~b}-\mathrm{RAD}$ sequencing identifies the candidate genes putatively associated with resistance to ivermectin in Haemonchus contortus. Parasit Vectors 2017; 10(1): 31. http://dx.doi.org/10.1186/s13071-016-1959-6. PMid:28095895.

MacQueen AJ, Baggett JJ, Perumov N, Bauer RA, Januszewski T, Schriefer L, et al. ACT-5 Is an Essential Caenorhabditis elegans Actin Required for Intestinal Microvilli Formation. Mol Biol Cell 2005; 16(7): 3247-3259. http://dx.doi.org/10.1091/mbc.e04-12-1061. PMid:15872090.

Madden T. The blast sequence analysis tool. In: National Center for Biotechnology. The NCBI Handbook. 2nd ed. Bethesda: NCBI; 2013. p. 1-6.

Mádi A, Mikkat S, Koy C, Ringel B, Thiesen HJ, Glocker MO. Mass spectrometric proteome analysis suggests anaerobic shift in metabolism of Dauer larvae of Caenorhabditis elegans. Biochim Biophys Acta 2008; 1784(11): 1763-1770. http://dx.doi.org/10.1016/j.bbapap.2008.05.017. PMid:18620082.

Qiao F, Luo L, Peng H, Luo S, Huang W, Cui J, et al. Characterization of three novel fatty acid- and retinoid-binding protein genes (Ha-far-1, Ha-far-2 and Hf-far-1) from the cereal cyst nematodes Heterodera avenae and $H$. filipjevi. PLoS One 2016; 11(8): e0160003. http://dx.doi. org/10.1371/journal.pone.0160003. PMid:27479008.

Raza A, Kopp SR, Bagnall NH, Jabbar A, Kotze AC. Effects of in vitro exposure to ivermectin and levamisole on the expression patterns of $\mathrm{ABC}$ transporters in Haemonchus contortus larvae. Int J Parasitol Drugs Drug Resist
2016; 6(2): 103-115. http://dx.doi.org/10.1016/j.ijpddr.2016.03.001. PMid:27164439.

Rey-Burusco MF, Ibanez-Shimabukuro M, Gabrielsen M, Franchini GR, Roe AJ, Griffiths K, et al. Diversity in the structures and ligand-binding sites of nematode fatty acid and retinol-binding proteins revealed by Na-FAR-1 from Necator americanus. Biochem J 2015; 471(3): 403-414. http://dx.doi.org/10.1042/BJ20150068. PMid:26318523.

Rost BR, Schneider F, Grauel MK, Wozny C, G Bentz C, Blessing A, et al. Optogenetic acidification of synaptic vesicles and lysosomes. Nat Neurosci 2015; 18(12): 1845-1852. http://dx.doi.org/10.1038/ nn.4161. PMid:26551543.

Rushforth AM, White CC, Anderson P. Functions of the Caenorhabditis elegans regulatory myosin light chain genes $m l c-1$ and mlc-2. Genetics 1998; 150(3): 1067-1077. PMid:9799259.

Sambrook JR, David W. The condensed protocols from molecular cloning: a laboratory manual. New York: Cold Spring Harb Lab Press; 2006.

Shaye DD, Greenwald I. OrthoList: a compendium of $C$. elegans genes with human orthologs. PLoS One 2011; 6(5): e20085. http://dx.doi. org/10.1371/journal.pone.0020085. PMid:21647448.

Shevchenko A, Tomas H, Havlis J, Olsen JV, Mann M. In-gel digestion for mass spectrometric characterization of proteins and proteomes. Nat Protoc 2006; 1(6): 2856-2860. http://dx.doi.org/10.1038/nprot.2006.468. PMid:17406544.

Silva JP, Furtado AP, Santos JN. Proteomic profile of Ortleppascaris sp.: A helminth parasite of Rhinella marina in the Amazonian region. Int $J$ Parasitol Parasites Wildl 2014; 3(2): 67-74. http://dx.doi.org/10.1016/j. ijppaw.2014.03.003. PMid:25161903.

Szklarczyk D, Morris JH, Cook H, Kuhn M, Wyder S, Simonovic M, et al. The STRING database in 2017: quality-controlled proteinprotein association networks, made broadly accessible. Nucleic Acids Res 2017; 45(D1): D362-D368. PMid:27924014.

Tabuse Y, Nabetani T, Tsugita A. Proteomic analysis of protein expression profiles during Caenorhabditis elegans development using two-dimensional difference gel electrophoresis. Proteomics 2005; 5(11): 2876-2891. http:// dx.doi.org/10.1002/pmic.200401154. PMid:15996007.

van Wyk JA, Malan FS. Resistance of field strains of Haemonchus contortus to ivermectin, closantel, rafoxanide and the benzimidazoles in South Africa. Vet Rec 1988; 123(9): 226-228. http://dx.doi.org/10.1136/ vr.123.9.226. PMid:3176284. 